\title{
Hosts of the parasitoid Pachycrepoideus vindemmiae (Rondani) (Hymenoptera: Pteromalidae) of medical-veterinary and economic importance collected in the State of Goiás, Brazil
}

\author{
Carlos Henrique Marchiori ${ }^{1, ~ *}$, Lígia Miranda Ferreira Borges ${ }^{2}$, Lorena Lopes Ferreira ${ }^{2}$ \\ ${ }^{1}$ Instituto Federal Goiano/ Universidade Federal de Goiás, Brazil, Instituto de Patologia Tropical e Saúde Pública, Rua 235 - s/n, Setor \\ Universitário, Goiânia, Goiás, Brasil \\ ${ }^{2}$ Universidade Federal de Goiás. Campus Samambaia (Campus II), Prédio da Reitoria, Caixa Postal: 131, Goiânia, Goiás, Brasil
}

\section{Email address:}

chmarchiori@yahoo.com.br(C.H. Marchiori),borges.ligia@gmail.com(L. M. F. Borges), loren4_lopes@hotmail.com(L. L. Ferreira)

To cite this article:

Carlos Henrique Marchiori, Lígia Miranda Ferreira Borges, Lorena Lopes Ferreira. Hosts of the Parasitoid Pachycrepoideus vindemmiae (Rondani) (Hymenoptera: Pteromalidae) of Medical-Veterinary and Economic Importance Collected in the State of Goiás, Brazil. American Journal of Life Sciences. Vol. 1, No. 5, 2013, pp. 228-231. doi: 10.11648/j.ajls.20130105.14

\begin{abstract}
Pachycrepoideus vindemmiae (Rondani) (Hymenoptera: Pteromalidae) is a solitary parasitoid containing a great number of Diptera in the families Anthomyiidae, Calliphoridae, Muscidae, Tachinidae and Tephritidae. This species presents a diversified distribution and it has been found in North America, Canada and Africa The study determined the species of hosts of the parasitoid P. vindemmiae in cattle dung, human feces, manure kidneys, cattle liver, pig carcass, fish and fruit. The pupae were obtained by the flotation method. They were individually placed in gelatin capsules until the emergence of adult flies or their parasitoids. The overall percentage of parasitism was $6.8 \%$. Through this study, knowledge of the bioecology and geographical distribution of parasitoids of dipterous in Brazil.
\end{abstract}

Keywords: Insecta, Diptera, Biocontrol

\section{Introduction}

The Diptera are an excellent model for studying synanthropy, not only because their ecological importance, but also because their medical-veterinary characteristics as vectors for etiological agents such as ameba cysts, helminthes eggs, pathogenic enterobacteria, viruses and fungi [1].

The Pteromalidae is cosmopolitan in distribution and is one of the largest families of Chalcidoidea, containing over 3000 recognized species in nearly 600 genera. The modes of carnivore encountered in the family are very diverse, encompassing idiobiosis and koinobiosis, ectoparasitism and endoparasitism, solitary and gregarious and primary and secondary parasitoids [2]. The main contribution of pteromalids is their control over muscoid flies, especially the house-fly and the stable fly [2].

Pachycrepoideus vindemmiae (Rondani) (Hymenoptera: Pteromalidae) is a solitary parasitoid containing a great number of Diptera in the families Anthomyiidae,Calliphoridae, Muscidae, Tachinidae and
Tephritidae. This species presents a diversified (cosmopolitan) distribution and it has been found in North America, Canada and Africa [2].

The objective of this paper was to determine the hosts of the parasitoid $P$. vindemmiae collected in several substrates, in State of Goiás, Brazil.

\section{Material and Methods}

\subsection{Experiment with Pig Carcasses}

In a natural area, two pig carcasses (Sus scrofa) weighing approximately $10 \mathrm{~kg}$ each were used as bait. The pigs were killed mechanically with a blow to the head and were immediately placed inside metal frame cages to exclude large vertebrate scavengers. Underneath the cages, metal trays with sawdust were placed to collect the pupae. The pupae were extracted by means of flotation in water. The pupae were individually placed in gelatin capsule. The study were conducted at the "Faculdade de Agronomia" settled in the city of Itumbiara, GO $\left(18^{\circ} 25^{\prime} \mathrm{S}-49^{\circ} 13^{\prime} \mathrm{W}\right)$, Brazil. 


\subsection{Experiment with Cattle Dung}

The study were conducted at the "Faculdade de "Agronomia" settled in the city of Itumbiara, GO $\left(18^{\circ} 25^{\prime} \mathrm{S}-\right.$ $49^{\circ} 13^{\prime} \mathrm{W}$ ), and the Veterinary and Zootechnics School of the Federal University of Goiás, in the municipality of Goiânia (16 $40^{\circ}$ 'S and 49 $\left.16^{\prime \prime} \mathrm{W}\right)$, Brazil. Every fortnight, 10 plates of fecal cake (of approximately $3 \mathrm{~kg}$ each) were produced from fresh bovine feces that were collected immediately after defecation in pastures of Brachiaria brizantha (Hochst ex. A Rich) and in corrals. The material was collected in plastic buckets and was homogenized. It was then placed in 10 round plastic supports of $20 \mathrm{~cm}$ in diameter, with a hole to allow rainwater to drain away. This methodology was used for precise determination of the time between the emission of the fecal cake and its collection. The feces remained exposed (five in the pastures and five in the corrals) for 15 days. After this period, the feces were taken to the laboratory for extraction of pupae by means of the flotation method. The pupae were removed with the aid of a sieve; they were counted and individually stored in gelatin capsules (number 00) until the flies and/or parasitoids emerged. The parasitoids and flies that emerged were identified with the aid of a stereoscopic microscope and were conserved in $70 \%$ alcohol.

\subsection{Experiment with Human Feces, Cattle Kidneys, Cattle Liver, Fish and Fruit}

The study were conducted at the "Faculdade de 'Agronomia" settled in the city of Itumbiara, GO $\left(18^{\circ} 25^{\prime} \mathrm{S}-\right.$ $\left.49^{\circ} 13^{\prime} \mathrm{W}\right)$. The flies were collected by using traps, made of dark cans measuring $19 \mathrm{~cm}$ in height and $9 \mathrm{~cm}$ in diameter, with two openings resembling blinders, located in the lowest third of the can, to allow flies to enter. The top of the can was connected to a nylon funnel that was open at both ends, with the base pointing down. This was wrapped in plastic bags, so that when they were removed, the flies and parasitoids could be collected. The following items were used as bait: human feces, cattle kidneys, cattle liver, pig carcass, fish and fruit, which were placed inside the cans, over a layer of earth. Six traps were used and they were hung on trees at a height of one meter above the ground, two meters apart from each other. The insects collected were taken to the laboratory, sacrificedwith ethyl ether and kept in 70\% alcohol for further identification. To obtain the parasitoids, the contents of the traps were placedin plastic containers with a layer of sand for use as a substrate for transformation of the larvae into pupae. This sand was sifted after being in the fields for 15 days and the pupae were extracted from it and were individually placed in gelatin capsules (number 00) in order to obtain the flies and/or parasitoids.

\subsection{Experiment with Manure Chicken}

The study were conducted at the farm "Casa do Sítio" settled in the city of Itumbiara, GO $\left(18^{\circ} 25^{\prime} \mathrm{S}-49^{\circ} 13^{\prime} \mathrm{W}\right)$ and Instituto Federal Goiano, Campus Morrinhos, settled in the city of Morrinhos, GO $\left(17^{\circ} 43^{\prime} \mathrm{S}, 4^{\circ} 05^{\prime} \mathrm{W}\right)$. The feces collected originated from 40 "Hyline" chickens that were reared in a cage system. The feces that accumulated under the cages varied in terms of moisture content, ranging from pasty to firm. Fresh feces (pasty), which were collected immediately after emission, were placed in five basins of 30 $\mathrm{cm}$ in diameter and $12 \mathrm{~cm}$ in height, and were left in an appropriate environment, in a dry location, for 15 days. For extraction of the pupae using the floatation method, the routine procedures for this type of experiment were modified. The parasitoids and flies that emerged were identified with the aid of a stereoscopic microscope.

\subsection{Percentage of Parasitism}

The total percentage parasitism was calculated by means of the number of pupae parasitized, divided by the total number of pupae collected, and multiplied by 100 . The percentage parasitism of each parasitoid species was calculated by means of the number of pupae parasitized per species of parasitoid, divided by the total number of pupae from that host, and multiplied by 100 .

\section{Results and Discussion}

Between January 1999 and March 2013, 14.471 dipterous pupae were collected from several substrates (Table 1). Among the hosts collected, the species Chrysomya albiceps (Wiedemann) (Diptera: Calliphoridae) and Musca domestica L. (Diptera: Muscidae) stood out regarding their importance (medical-veterinary).

Chrysomya albiceps is of major medical and sanitary interest, because it is responsible for secondary myiasis and is a vector for pathogenic microorganisms. M. domestica is a species of great sanitary interest because of its synanthropic characteristic, abundance in urban areas, capacity to develop in several sorts of substrates and high reproductive capacity.

As shown in Table 1, 831 specimens of the parasitoid Pachycrepoideus vindemmiae (Rondani) (Hymenoptera: Pteromalidae) were obtained in seven substrates and from eleven different hosts. Probably due to the availability of resources, to the density of hosts and to the searching capacity of the parasitoids. Continuing presence of $P$. vindemmiae is favored in the environment through its ability to have several dipterous hosts, thus enhancing its potential as a biological agent keeper.

A great number of individuals were obtained from the host Zaprionus indianus Gupta (Diptera: Drosophilidae), accounting for around $27.5 \%$. Among the substrates, cattle kidneys presented higher diversity of hosts attacked by $P$. vindemmiae, accounting for $6.8 \%$ of the individuals collected (Table 1), which was probably due to the host density.

The first record published on the occurrence of this fly in the American continent was in khaki fruit in Santa Isabel, São Paulo, Brazil. Its poliphagy and relatively fast lifetime in high hot weather have contributed for its settling and dispersion through this country [6]. A loss of 50\% was recorded in the fig production in the state of São Paulo, 
Brazil due to this fly [6].

The biological control using $P$. vindemmiae can be an effective approach to reduce the economic losses caused by the melon fly, Bactrocera cucurbitae (Coquillett) (Diptera: Tephritidae) in China [7].

The total percentage parasitism observed was around $5.7 \%$. The host showing the highest percentage parasitism was C. albiceps in cattle liver (Table 1), and this was probably due to the seasonality factor presented by this species. Presently in Costa Rica $P$. vindemmiae is being tested for its potential to control the fruit fly [2]. Pachycrepoideus vindemmiae is a parasitoid of a great number of Diptera, including species of Calliphora, Lucilia,Hylemya, Drosophila, Rhagoletis, Paratheresia, Anastrepha, Ceratitis, Phormia, Phaenicia and Haematobia $[3,4-5]$.

Among the means for controlling flies, chemical insecticides are the most widely used. However, these may lose their efficiency as populations become resistant to them [8]. The appearance of resistance to insecticides explains the growing need to introduce alternative control programs aimed towards insects control [8].

As a possibility to control these insects, the natural regulators can be used, such as parasitoids that are the responsible agents for the reduction of the insects pests populations [6].

\section{Conclusion}

P. vindemmiae has the potential for host range expansion and thus non-target impact on other beneficial parasitoids of Diptera. The fact that $P$. vindemmiae develops in several dipterous insects and substratesfavors its continuing presence in the environment, thereby enhancing its potential as a biological agent keeper.

Table 1. Hosts of the parasitoid Pachycrepoideus vindemmiae (Rondani) (Hymenoptera: Pteromalidae) of medical-veterinary and economic importance collected from January 1999 to March 2013 in Goiás, Brazil

\begin{tabular}{|c|c|c|c|c|}
\hline Type of substrates & Number of dipterous & Species of dipterous & $\begin{array}{c}\text { Number of } P . \\
\text { vindemmiae }\end{array}$ & Percentage \\
\hline Pig carcass & 302 & Ophyra sp. & 06 & 19.8 \\
\hline \multirow[t]{2}{*}{ Cattle dung } & 3370 & Musca domestica & 14 & 0.4 \\
\hline & 4521 & Sarcophagula occidua & 11 & 0.2 \\
\hline \multirow[t]{5}{*}{ Human feces } & 123 & Fannia pusio & 07 & 5.7 \\
\hline & 52 & Oxysarcodexia thornax & 08 & 15.3 \\
\hline & 12 & Sarcodexia lambens & 04 & 33.3 \\
\hline & 165 & Sarcophagula sp. & 39 & 23.6 \\
\hline & 220 & Poecilosomella sp. & 40 & 18.1 \\
\hline Cattle liver & 1700 & Fannia pusio & 02 & 0.1 \\
\hline Fruit & 1031 & Zaprionus indianus & 397 & 38.5 \\
\hline \multirow[t]{2}{*}{ Fish } & 40 & Oxysarcodexia thornax & 16 & 40.0 \\
\hline & 37 & Sarcodexia sp. & 04 & 10.8 \\
\hline \multirow[t]{7}{*}{ Manure kidneys } & 53 & Peckia chrysostoma & 01 & 1.8 \\
\hline & 45 & Chrysomya albiceps & 30 & 66.6 \\
\hline & 500 & Chrysomya megacephala & 3 & 0.6 \\
\hline & 43 & Fannia pusio & 2 & 4.6 \\
\hline & 2083 & Musca domestica & 237 & 11.4 \\
\hline & 81 & Palaeosepsis sp. & 8 & 9.8 \\
\hline & 93 & Ornidia obesa & 2 & 2.2 \\
\hline Total & 14471 & & 831 & \\
\hline
\end{tabular}

\section{References}

[1] J. M. D'Almeida, “Calyptrate Diptera (Muscidae and Anthomyiidae) of the State of Rio de Janeiro - I. Synanthropy", Memórias do Instituto Oswaldo Cruz, vol. 87, pp. 381-386, 1992.
[2] P. E. Hanson, I. D, Gauld (1995) The Hymenoptera of Costa Rica. Oxford University Press, Oxford. P. 839.

[3] A Malavasi, R A. Zucchi, (2000) Moscas-das-frutas de importância econômica no Brasil. Conhecimento básico e aplicado. Holos, Ribeirão Preto. P. 327. 
[4] C. H. Marchiori "Parasitóides de estágios imaturos de dípteros sinantrópicos coletados em vários ambientes em Itumbiara-GO", Acta Scientiarum Agronomy, vol. 22, pp. 655-661, 2000.

[5] C. H. Marchiori, A. M. S. Oliveira, F. F., Martins, F. S. Bossi and A. T. Oliveira, "Ocorrência de moscas frugívoras (Diptera: Tephritidae e Lonchaeidae) e seus parasitóides em Itumbiara-GO", Arquivo do Instituto Biológico, vol. 67, 139-141, 2000.

[6] C. R. Vilela, E. P. Teixeira and C. P. Stein, (1999) Nova praga nos figos: Zaprionus indianus Gupta, 1970. Informativo da Sociedade Entomológica do Brasil, vol. 4, pp. 1-5, 1999.
[7] H. Y. Zhao, L. Zeng, Y. Xu, Y.Y. Lu and G. W. Liang, "Effects of host age on the parasitism of Pachycrepoideus vindemmiae (Hymenoptera: Pteromalidae), an ectoparasitic pupal parasitoid of Bactrocera cucurbitae (Diptera: Tephritidae" Florida Entomological Society, vol. 96, pp. 451-457, 2013.

[8] G. A. R. Silveira, N. G. Madeira, A. M. Azeredo-Espin and C. Pavan "Levantamento de microhimenópteros parasitóides de dípteros de importância médico, veterinária no Brasil", Memórias do Instituto Oswaldo Cruz, vol. 84, pp.505-510, 1989. 